\title{
Information Needs and Source Information of Agricultural Extension Workers in DIY
}

D 0 I:10.18196/ agr.1212

\begin{abstract}
One of the important factors that contribute to agricultural development is information. As such agricultural extension workers that link agricultural agencies to the farmers must have adequate and up-to-date information about agricultural practices before they could inform, educate and train the farmers in method and techniques of farming. This study aims to determine the types of information needed by agricultural extension workers; to determine the sources of information used by the agricultural extension workers; and to determine the comparison between types of information with information sources used by agricultural extension workers. The present study was a descriptive study using a survey design and conducted at
\end{abstract}

Daerah Istimewa Yogyakarta (DIY) Province. The populations of the study consists 181 agricultural extension workers divisible in the district level, namely Sleman, Kulon Progo, Gunung Kidul dan Bantul. Sampling procedure in this study used cluster sampling. The method for gathering data from the respondents is based on a structured questionnaire. Descriptive statistics was to describe the characteristics of the respondents and the dependent variables of the study. As a result, most of agricultural extension workers strongly needed the innovation information in seeking information followed by extension service information and extension role information. The result of information sources used by agricultural extension worker for extension service information, innovation information and extension role information indicates that agricultural extension workers used interpersonal source. Most of them never sought information use Internet, they use radio more frequently than television and video, agricultural extension worker also used mass media as information source.

Keywords: information need, information source, agricultural extension worker.

\section{INTISARI}

Salah satu faktor penting yang berkontribusi terhadap pembangunan pertanian adalah informasi. Sebagai penyuluh pertanian yang menghubungkan lembaga pertanian kepada para petani harus memiliki informasi yang memadai dan up-to-date tentang praktek-praktek pertanian sebelum mereka menyampaikan, mendidik dan melatih para petani dalam metode dan teknik pertanian.

Penelitian ini bertujuan untuk mengetahui jenis-jenis informasi yang dibutuhkan oleh penyuluh pertanian; untuk menentukan sumber informasi yang digunakan oleh penyuluh pertanian; dan untuk menentukan perbandingan antara jenis informasi dengan sumber informasi yang digunakan oleh penyuluh pertanian. Penelitian ini merupakan penelitian deskriptif dengan menggunakan desain survei dan dilakukan di Daerah Istimewa Yogyakarta 
(DIY). Populasi penelitian terdiri 181 penyuluh pertanian dibagi di tingkat kabupaten, yakni Sleman, Kulon Progo, Gunung Kidul dan Bantul. Prosedur pengambilan sampel yang digunakan yaitu Cluster Sampling. Metode untuk mengumpulkan data dari responden berdasarkan kuesioner terstruktur. Statistik deskriptif digunakan untuk menggambarkan karakteristik responden dan variabel penelitian. Hasil penelitian menunjukkan bahwa sebagian besar penyuluh pertanian sangat membutuhkan informasi tentang inovasi dalam mencari informasi yang diikuti oleh informasi tentang pelaksanaan tugas penyuluh dan informasi tentang sistem penyuluhan pertanian. Sumber informasi yang digunakan oleh penyuluh pertanian untuk informasi tentang inovasi, informasi tentang pelaksanaan tugas penyuluh dan informasi tentang sistem penyuluhan pertanian, menunjukkan bahwa penyuluh pertanian digunakan sumber informasi interpersonal. Sebagian besar dari mereka tidak pernah mencari informasi penggunaan internet, radio lebih sering digunakan daripada televisi dan video. Penyuluh pertanian juga menggunakan media massa sebagai sumber informasi.

Kata kunci: kebutuhan informasi, sumber informasi, penyuluh pertanian.

\section{INTRODUCTION}

Efficacy of agricultural development is determined by the ability of human resources in managing agricultural system using scientific method and new technology. Therefore, to improve the agricultural human resources, especially farmers, requires reaching them through education, training and agricultural extension (Suryantini, 2003).

The role of extension can also be seen from the diffusion of inxnovation view (Rogers, 1995). According to this view, the role of the change agent is to diffuse innovations to the clients, in what might seem to be a one-way persuasion process. But for this change process to be effective, the change agents must provide the linkage with the clients' needs and problems to the change agency. This information is crucial in determining which innovations are most appropriate for diffusion to the clients. In short, according to the diffusion of innovation's view, one of the main roles of the change agents is to facilitate the flow of innovations from the change agency to the clients. For this type of communication to be effective, the innovations must be selected to match the clients' needs and problems.
According to Rivera (2001), agricultural extension receives relevant information from the agricultural education system and feeds-back field observations to this system. Extension is also professionally linked to the agricultural vocational and higher education systems in the sense that these systems also produce the agents who work in extension. The relationship between agricultural extension and agricultural research is even closer, because the knowledge that agricultural extension transfers is usually generated by agricultural research through applied and adaptive agricultural research development. According to Van den Ban and Hawkins (1996), extension organizations obtain the information from agriculture research, agriculture policy, and also psychological and social research. This information used by extension organization to be taught to extension agent what to be told to farmer on the chance of that the message will bring the change in management of farming system.

According to Mawardi (2004), farmers still need agricultural extension activities. Small-scale agriculture is still weak in many aspects, whereas the challenges faced are increasingly demanding; these farmers need extension activities which should be more intensive, sustainable and well directed. In Indonesia, the existences of extension policy and services have significant contribution to various programs of agriculture development. Extension agents have the special duty to conduct the technological development and disseminations result of study and also produce the extension materials. Iskak (2005) found that almost 63 percent of the potato farmer studied, never received information from agricultural extension agents. Meanwhile, more than 32 percent of the respondents stated that they occasionally received information from agricultural extension agents, even though, only 5 percent of the respondents obtained information from agricultural extension agents very frequently. These indicated that agricultural extension worker is still needed by farmers to increase the agricultural information and to assist farmers to solve their problems.

According to Sulaiman (2002), the implementation of decentralization policy in early 2001 has resulted in several fundamental changes in the organizational structure and management of government institutions dealing with agricultural innovation transfer. These changes have increased the ineffectiveness of extension organization and personnel. The implementation of decentralization policy has affected the number, position 
and the workplace of extension personnel, especially at the district level. The integration of extension function into agricultural services among a variety of agencies with similar role and function at provincial, district and field levels in this decentralization era, weakened the extension role and function.

According to Mawardi (2004), starting in 2001, with the implementation of regional autonomy, authority over agricultural extension was delegated to the regional governments. The delegation of this authority was expected to boost the performance of agricultural extension. Instead, the performance of agriculture extension has generally tended to deteriorate as well as showing signs of a loss of direction. The obstacles faced by agricultural extension in the regional autonomy era, include: (1) Differences in opinion between regional governments and the members of local assemblies in understanding agricultural extension and its role in agriculture development. (2) The limited budget allocations for agricultural extension activities from the regional governments. (3) The availability and support from agriculture information (technology, market prices, farming opportunities, etc.) provided by the BPPs (Rural Extension Center) are very limited. (4) The continuing decline in the capacity and managerial capability of the workers. As a consequence, the extension activities are rarely carried out.

According to Setyorini et al. (2006), in their study involving 118 agriculture extension workers studied in Bogor District, West Java, Indonesia, all of them never accessed the information through Internet, $20.34 \%$ never go to the library, and $64.4 \%$ never go to the university. These indicate that the extension agents seldom visit the institute outside their job environment to obtain the information or consult experts to solve the problems faced in supporting their duty. This matter will affect the quality of extension workers, such that they cannot give the information needed by farmers and do not assist farmers to solve their problems.

Agricultural information can be obtained from interpersonal sources, print media, electronic media (Rogers, 1960; Giles and Stansfield, 1990; Weiss, Van Crowder, and Bernardi, 2000), and organizational meeting (Suvedi, Campo, and Lapinski, 1999). Harun (2001) and Irawan et al. (2001) found that extension agents, as well as, agricultural extension workers are major interpersonal source of information relating to farming system. However, they often provided out-of-date technical information to the farmers. Extension workers did not provide useful assistance needed to solve farmers' problems. As a result, the farmers were mostly dissatisfied with the extension system. To solve this problem, extension agents need to develop their information seeking strategies to meet the farmers' information needs. By using strategy to seek information, they can have more up-to-date information to improve farmers' knowledge and farmers' needs.

Based on the above situation, the following questions are posed:

1. What are the types of information needed by extension workers?

2. What are the sources of information used by the agricultural extension workers?

3. How the comparison between types of information with information sources used by agricultural extension workers?

The specific objectives of the study are as follows:

1. To determine the types of information needed by agricultural extension workers.

2. To determine the sources of information used by the agricultural extension workers.

3. To determine the comparison between types of information with information sources used by agricultural extension workers.

\section{METHOD}

The study uses a survey design. Survey can be a powerful and useful tool for collecting data on human characteristics, attitudes, thoughts, and behavior. The study was conducted at Daerah Istimewa Yogyakarta (DIY) Province. DIY was chosen as the location of this study for the following reasons: First, Daerah Istimewa Yogyakarta has agricultural large agricultural area with good irrigation system. Secondly, the area has a well developed agricultural extension organization and an intensive farming area where almost all of the villages are being served by the agricultural extension workers; and lastly there is an easy accessibility to all parts of the area.

The populations of the study consisted of the agricultural extension workers in the location of the study. Population of the study consisted of 338 the AEWs in Daerah Istimewa Yogyakarta. Daerah Istimewa Yogyakarta (DIY) Province has five districts (Kota Yogya, Sleman, Bantul, Gunung Kidul and Kulon Progo). From districts 
TABLE I. PROBABILITY SAMPLING PROCEDURES OF AGRICULTURAL EXTENSION WORKERS

\begin{tabular}{lllll}
\hline No & District & $\begin{array}{l}\text { Number of } \\
\text { AEWs }\end{array}$ & Proportionate sampling & $\begin{array}{l}\text { Number of AEWs } \\
\text { for sample }\end{array}$ \\
\hline 1 & Sleman & 105 & $(181 / 338) \times 105=56.23$ & 56 \\
2 & Bantul & 52 & $(181 / 338) \times 52=27.85$ & 28 \\
3 & Gunung Kidul & 132 & $(181 / 338) \times 132=70.68$ & 71 \\
4 & Kulon Progo & 49 & $(181 / 338) \times 49=26.24$ & 26 \\
\hline & Total & 338 & & 181 \\
\hline
\end{tabular}

were selected for the study, namely Sleman, Kulon Progo, Gunung Kidul dan Bantul. Kota Yogya was not included as sample in this study because it ineligible as a sample as the number of agricultural extension workers is small, that is only seven agricultural extension workers. Number of agricultural extension workers in Kota Yogya cannot be compared with the number of the agricultural extension workers from other districts. Sleman district has 105 agricultural extension workers, Kulon Progo district has 49 agricultural extension workers, Gunung Kidul district has 132 agricultural extension workers and Bantul district has 52 agricultural extension workers.

A sample is a subgroup of a population from which the researcher makes an inference about the population. To achieve a valid generalization of the result, the sample must represent the population. The sample was considered representative when the characteristics of the sample are similar to the characteristics of the population. A representative sample means that the sample selected reflects the parameters of the population. Therefore, the procedure of sample selection must provide an equal chance for each member of the population to be selected.

This study used proportionate cluster sampling technique because the size in every cluster is different. First, the researcher obtained the list of agricultural extension workers in Daerah Istimewa Yogyakarta Province from Provincial Agricultural Service Office (Dinas Pertanian Tingkat Propinsi), data on February 15, 2008. The list of Agricultural extension workers are 338 agricultural extension workers, in five districts (Table 1).

Secondly, sampling procedure AEWs in every district used proportionate cluster sampling technique. This study only used four districts, because these districts as agricultural areas. Kota Yogyakarta has more industrial areas with very limited agricultural area.

The number of all agricultural extension workers from four districts in DIY, except Kota Yogya is 338. For random sampling, a list of agricultural extension workers was obtained from each district. Based on the table presented by Krejcie and Morgan (1970), a sample size of 181 was considered appropriate for a population of 338 agricultural extension workers. For every district, respondents were randomly selected based on the sample size to the Table 1.

A structured-questionnaire was used as a means for data collection. Babbie (2005) states that a standard designed questionnaire is an effective method to obtain data in the same form all respondents. The questionnaire is designed to measure the dependent and independent variables. The questionnaire was constructed in English (Appendix A), and then translated into Indonesian language (Appendix B). The questionnaire consisted of six parts, namely, Part I: characteristic of the agricultural extension workers, Part II: information needed by agricultural extension workers, Part III: information sources used by agricultural extension workers.

Questionnaires were distributed through the Rural Agricultural Center for each district using drop and collect method, with instructions that the completed questionnaires were collected after three days. Agricultural extension workers from each district as sample in this study was taken randomly appropriate the sampling procedure in methodology.

Descriptive statistics was used to describe the characteristics of the respondents and the variables of the study. The frequency distribution and the summary statistics used were, mean, standard deviation, minimum and maximum values. The characteristics of the respondents included gender, age, education, working experience and current position of agricultural extension workers.

\section{FINDINGS AND DISCUSSIONS}

This chapter presets the characteristics of the agricultural extension workers, information needed by agricultural extension workers, information sources used by agricultural extension workers.

\section{CHARACTERISTICS OF THE AGRICULTURAL EXTENSION WORKERS}

This section consists of the descriptions of agricultural extension workers in terms of gender, age, education, working experience, and current position. Table 3 presents the frequency distribution and the summary statistics of the agricultural extension workers in terms the above variables. 
TABLE 2. DISTRIBUTION OF THE AGRICULTURAL EXTENSION WORKERS BY GENDER, AGE, EDUCATION, WORKING EXPERIENCE AND CURRENT POSITION $(\mathrm{N}=18 \mathrm{I})$

\begin{tabular}{|c|c|c|}
\hline CHARACTERISTICS & FREQUENCY & PERCENTAGE $(\%)$ \\
\hline \multicolumn{3}{|l|}{ Gender } \\
\hline Male & 115 & 85.6 \\
\hline Female & 26 & 14.4 \\
\hline \multicolumn{3}{|l|}{ Age (year) } \\
\hline$<40$ & 4 & 2.2 \\
\hline $40-45$ & 42 & 23.2 \\
\hline $46-50$ & 88 & 48.6 \\
\hline$>50$ & 47 & 26.0 \\
\hline \multicolumn{3}{|l|}{$($ mean $=48.18 ; S D=3.75 ;$ range $=38-60)$} \\
\hline \multicolumn{3}{|l|}{ Education } \\
\hline Senior High school & 28 & 15.5 \\
\hline Diploma & 68 & 37.6 \\
\hline Bachelor's degree & 83 & 45.9 \\
\hline Master's degree & 2 & 1.1 \\
\hline \multicolumn{3}{|l|}{ Working experience (year) } \\
\hline$<10$ & 8 & 4.4 \\
\hline $10-15$ & 3 & 1.7 \\
\hline $16-20$ & 19 & 10.5 \\
\hline $21-25$ & 55 & 30.4 \\
\hline $\begin{array}{l}>25 \\
(\text { mean }\end{array}=24.75 ; S D=6.02 ;$ range $\left.=1-37\right)$ & 96 & 53.0 \\
\hline \multicolumn{3}{|l|}{ Current position } \\
\hline Expert Middle-level Agricultural Extension & 9 & 5.0 \\
\hline Expert Young Agricultural Extension & 15 & 8.3 \\
\hline Expert First Agricultural Extension & 8 & 4.4 \\
\hline Skilled Agricultural Extension Supervisor Executive & 71 & 39.2 \\
\hline Skilled Agricultural Extension Higher Executive & 76 & 42.0 \\
\hline Skilled Agricultural Extension Executive & 2 & 1.1 \\
\hline
\end{tabular}

Most of the respondents (85.6 percent) are males and 14.4 percent were females. The reason for this is related to the nature of work. The job of agricultural extension workers involves much travel, often over difficult terrain and with overnight stay to meet with farmers, and the agricultural extension workers usually deal with male rather than female farmers.

The average age of respondents was 48 years old, ranging from 38 years to 60 years old. Agricultural extension workers fell within the age group of 46 years to 50 years is 48.6 percent, while 26 percent were in the group of 50 years old and older. The age group 40 years to 45 years and that of 40 years and below contribute to 23.2 percent and 2.2 percent of the agricultural extension workers, respectively. This indicates the that respondents are in the late middle age group.

The level of education of agricultural extension workers ranged from senior high school to master's degree. A high percentage of the respondents (45.9 percent) have bachelor degree, 37.6 percent have diploma, and 15.5 percent have senior high school education. The highest level of education achieved by the agricultural extension workers is a master's degree which constitutes more than one percent of the respondents.

The agricultural extension workers have an average working experience up to 25 years, and the range is from 1 year to 37 years. A half (53 percent) of agricultural extension workers have working experience more than 25 years, 30.4 percent have working experience 21 years to 25 years, 10.5 percent had working experience 16 years to 20 years, 1.7 percent had working experience 10 years to 15 years. The agricultural extension workers who had less than 10 years of experience occupied 4.4 percent. This means that most of agricultural extension workers have long working experience.

The position of the agricultural extension workers distinguish based on the in level of education and the type of work done by agricultural extension workers. It is found that the level of education increases with the complex its on the work kind that was carried out.

The position of the agricultural extension workers could be distinguished from the highest level to the level lowest, namely, Expert Middle-level Agricultural Extension, Expert Young Agricultural Extension, Expert First Agricultural Extension, Skilled Agricultural Extension Supervisor, Skilled Agricultural Extension Higher Executive, and Skilled Agricultural Extension Executive.

Forty two percent of the agricultural extension workers have position of Skilled Agricultural Extension Higher Executive, 39.2 percent had Skilled Agricultural Extension Supervisor position, 8.3 percent had Expert Young Agricultural Extension position, 5 percent had Expert Middle-level Agricultural Extension position, 4.4 percent had Expert First Agricultural Extension position and 1.1 percent had Skilled Agricultural Extension position.

\section{TYPES OF INFORMATION NEEDED BY AGRICUL- TURAL EXTENSION WORKERS}

Information that needed by agricultural extension workers are categorized into three information types, that is extension service information, innovation information, and extension role information. Table 4 illustrates that all of the respondents needed and strongly needed the 
three types of information. There is no agricultural extension workers that do not need or slightly needed such information.

\section{TABLE 3. DISTRIBUTION OF THE AGRICULTURAL EXTENSION WORKERS BY INFORMATION NEED $(\mathrm{N}=18 \mathrm{I})$}

\begin{tabular}{lll}
\hline TYPE OF INFORMATION & MEAN & SD \\
\hline Extension service information & 3.70 & 0.461 \\
Innovation information & 3.74 & 0.440 \\
Extension role information & 3.61 & 0.488 \\
\hline
\end{tabular}

Scale: 1 = Not Needed, 2 = Slightly Needed, 3 = Needed, 4 = Strongly Needed

More than 50 percent of the agricultural extension workers mentioned strongly needed the innovation information (74 percent), extension service information (69.4 percent) and extension role information (61.3 percent). Moreover agricultural extension workers also needed extension role information (38.7 percent), extension service information (30.4 percent), and innovation information (26 percent).

This finding indicates that most of the respondents needed innovation information rather than extension service information and extension role information, since innovation information is related to the task of the agricultural extension workers that is give information to the farmers about new innovation and to resolve problems that are faced by the farmers. As mentioned by Atkin (1973) individuals seek information to meet his or her information need to support his or her decision making and to reinforce his or her performance. This finding was consistent with Havelock (1978) who asserted that the agricultural extension workers as change agent also serve as communications links between the professionals in the knowledge centers and the farmers.

\section{INFORMATION SOURCES USED BY AGRICUL- TURAL EXTENSION WORKERS}

Sources of information which agricultural extension workers used in seeking information are interpersonal source, printed media source, electronic media, scientific meeting source and personal experience. Information source used by agricultural extension workers also distinguished in appropriate with the type of information, which is extension service information, innovation information and extension role information.

\section{EXTENSION SERVICE INFORMATION}

Extension service information is information about the implementation of agricultural extension by agricultural extension workers which were begun with preparing the extension material, coordinating with the farmers, giving information about price, infrastructure of agriculture, marketing, increasing quality of agricultural product, post-harvest; and evaluating the extension activities that has been carried out. Table 5 presents the usage of information source by agricultural extension workers on extension service information. Most of agricultural extension workers use interpersonal source followed by printed media, personal experience, scientific meeting and electronic media.

a. Interpersonal source

The interpersonal sources consist of discussion with agricultural researchers, discussion with senior officers, discussion colleagues, discussion with farmers, and correspondence with researchers. More than 50 percent (56.4 percent) of the agricultural extension workers very frequently sought information by discussion with colleagues, 39.2 percent very frequently discussed with farmers, and 0.6 percent very frequently discussed with agricultural researcher and do correspondence with researcher. Forty-seven percent of the agricultural extension workers frequently discuss with senior officers and 46 percent frequently discuss with farmers. Forty-five percent of the agricultural extension workers seldom discuss with researcher and 68.5 percent never do correspond with researcher.

Most of agricultural extension workers very frequently sought extension service information by having discussion with colleagues, because almost every day they meet in the office and they discussion or sharing about their extension service information.

b. Printed media

Agricultural extension workers sought the information through printed media source from agricultural newspapers, agricultural magazines, brochures/ leaflets, textbooks, books published by AARD, and journals. Almost 60 percent (59.7 percent) of the agricultural extension workers seldom seek information via journals and only 0.6 percent of the agricul- 
TABLE 4. DISTRIBUTION OF THE AGRICULTURAL EXTENSION WORKERS BY FREQUENCY OF USING INFORMATION SOURCES FOR EXTENSION SERVICE INFORMATION $(\mathrm{N}=181)$

\begin{tabular}{lll}
\hline TYPES OF INFORMATION SOURCE & MEAN & $\begin{array}{l}\text { STANDARD } \\
\text { DEVIATION }\end{array}$ \\
\hline a. Interpersonal: & & \\
Discussion with colleagues & 4.48 & 0.68 \\
Discussion with farmers & 4.19 & 0.84 \\
Discussion with senior officers & 3.80 & 0.85 \\
Discussion with agricultural researchers & 1.77 & 0.76 \\
Correspondence with researchers & 1.44 & 0.74 \\
Overall & 3.13 & 0.77 \\
b. Printed Media: & & \\
Agricultural newspapers & 3.41 & 1.19 \\
Agricultural magazines & 3.04 & 0.99 \\
Brochure/leaflet & 2.85 & 0.85 \\
Text books & 2.36 & 0.88 \\
Books published by the AARD & 2.34 & 0.85 \\
Journals & 2.22 & 0.79 \\
Overall & 2.70 & 0.93 \\
c. Personal Experience: & & \\
Own observation and experience & 3.05 & 0.98 \\
Own tests and research & 1.99 & 0.89 \\
Overall & 2.52 & 0.94 \\
d. Scientific Meeting: & & \\
Training & 2.62 & 0.96 \\
Seminars & 2.48 & 0.80 \\
Field research project & 1.82 & 0.88 \\
Overall & 2.30 & 0.88 \\
e. Electronic Media: & & \\
Television & 2.91 & 1.19 \\
Radio & 2.81 & 1.11 \\
Video & 1.81 & 1.01 \\
Internet & 1.60 & 0.92 \\
Overall & 2.28 & 1.06 \\
\hline & & \\
\hline & & \\
& &
\end{tabular}

Scale: $1=$ Never; $2=$ Seldom, $3=$ Occasionally $4=$ Frequently, $5=$ Very Frequently

tural extension workers seek the information from journals. More than 40 (46.4) percent of the agricultural extension workers occasionally use brochure/ leaflet for seeking information. Agricultural extension workers frequently use agricultural newspaper (30.9 percent).

c. Personal experience

Agricultural extension workers seek information by personal experience through own observation and experience, and own test and research. Agricultural extension workers stated that they seldom get information through their own test and research (43.1 percent), and more than 30 percent ( 32.6 percent) of the agricultural extension workers never seek information through their own test and research and only 6.6 percent of them seek information through their own observation and experience, and 0.6 percent of the agricultural extension workers very frequently seek information through their own test and research.

d. Scientific meeting

Agricultural extension workers use scientific meeting source in seeking information. A total of 48.6 percent seldom seek information through seminar, 35.4 percent seldom seek information through training, and 39.8 percent seldom seek information through field research project. Agricultural extension workers never seek information through field research project (42.5 percent) and only 0.6 percent of them seek information through the field research project.

e. Electronic media

Electronic media that agricultural extension workers use in seeking information consist of television, radio, video, and Internet. Agricultural extension workers never seek information using the Internet (61.3 percent) and only 1.7 percent agricultural extension workers use Internet in seeking information. Agricultural extension workers frequently use television (23.2 percent); use radio (37.6 percent) and 29.3 percent of them seldom use video.

\section{INNOVATION INFORMATION}

Innovation information is information about new innovation, advantages and disadvantages of new innovation which were seen from technical, economic and social aspects; disseminating of new innovation and farmer's responses on new innovation as well. Table 6 presents the usage of information source by agricultural extension workers on innovation information. Most of agricultural extension workers use interpersonal source followed by printed media, personal experience, electronic media and scientific meeting. 


\section{TABLE 6. DISTRIBUTION OF THE AGRICULTURAL EXTENSION WORKERS BY FREQUENCY OF USING INFORMATION SOURCE FOR INNOVATION INFORMATION $(\mathrm{N}=\mathrm{I8I})$}

\begin{tabular}{lcl}
\hline TYPES OF INFORMATION SOURCE & MEAN & $\begin{array}{l}\text { STANDARD } \\
\text { DEVIATION }\end{array}$ \\
\hline a. Interpersonal: & & \\
Discussion with colleagues & 4.28 & 0.72 \\
Discussion with farmers & 4.14 & 0.85 \\
Discussion with senior officers & 3.70 & 0.88 \\
Discussion with agricultural researchers & 2.08 & 0.97 \\
Correspondence with researchers & 1.65 & 0.90 \\
Overall & 3.17 & 0.86 \\
b. Printed Media: & & \\
Agricultural newspapers & 3.41 & 1.18 \\
Agricultural magazines & 3.13 & 0.98 \\
Brochure/leaflet & 2.90 & 0.75 \\
Text books & 2.48 & 0.95 \\
Books published by the AARD & 2.39 & 0.76 \\
Journals & 2.28 & 0.74 \\
Overall & 2.76 & 0.89 \\
c. Personal Experience: & & \\
Own observation and experience & 3.04 & 1.06 \\
Own tests and research & 2.29 & 0.87 \\
Overall & 2.66 & 0.96 \\
d. Scientific Meeting: & & \\
Training & 2.61 & 0.96 \\
Seminars & 2.43 & 0.81 \\
Field research project & 1.97 & 0.89 \\
Overall & 2.34 & 0.88 \\
e. Electronic Media: & & \\
Television & 3.06 & 1.16 \\
Radio & 3.00 & 1.09 \\
Video & 1.92 & 1.04 \\
Internet & 1.81 & 0.94 \\
Overall & 2.44 & 1.06 \\
\hline & & \\
\hline & &
\end{tabular}

Scale: $1=$ Never, $2=$ Seldom, $3=$ Occasionally, $4=$ Frequently, $5=$ Very Frequently

a. Interpersonal source

The interpersonal sources consist of discussion with agricultural researchers, discussion with senior officers, discussion with colleagues, discussion with farmers, and correspondence with researchers. Agricultural extension workers frequently seek information by discussion with colleagues (47.5) and frequently discuss with farmers (44.8 percent). Only 2 percent very frequently discuss with agricultural researcher, and 0.6 percent corresponds with researcher. Agricultural extension workers frequently discuss with senior officer (49.7 percent). Agricultural extension workers never discuss with agricultural researcher (30.4 percent) and never correspond with researcher (68 percent).

b. Printed media

Agricultural extension workers who are seeking for information through printed media sources do it through reading agricultural newspapers, agricultural magazines, brochure/leaflet, textbooks, books published by AARD, and journal. Agricultural extension workers seldom seek information by reading journals (55.8 percent) and only 0.6 percent of the agricultural extension workers seek information by brochure/ leaflet. Agricultural extension workers occasionally use brochure/leaflet for seek information (50.3 percent). Agricultural extension workers frequently use agricultural newspapers ( 36.5 percent). There is no agricultural extension workers use books published by the AARD and journals in seeking information.

c. Personal experience

Agricultural extension workers that seeking information by personal experience consist of own observation and experience; and own test and research. Agricultural extension workers stated seldom got information through own test and research (51.9 percent). They occasionally seeking information through own test and research (23.8 percent) and seeking information through own observation and experience. Only 1.7 percent agricultural extension workers very frequently seeking information through own test and research.

d. Scientific meeting

Agricultural extension workers also use scientific meeting source in seeking information. Agricultural extension workers seldom seek information through seminar (45.9 percent), 36 percent occasionally seek information through training and 44.2 percent seldom seek information through field research project. Agricultural extension workers never seeking information through field research project (33.1), and only 0.6 percent agricultural extension workers seek information through field research project.

e. Electronic media 
Electronic media that the agricultural extension workers use in seeking information consist of television, radio, video, and Internet. Agricultural extension workers never seek information using Internet (45.9 percent), 35.9 percent of the agricultural extension workers seldom use the Internet and only 1.1 percent of the agricultural extension workers use the Internet in seeking the information. Agricultural extension workers occasionally use television (34.8 percent); use radio (38.7 percent) and 43.6 percent of them never use the video.

\section{EXTENSION ROLE INFORMATION}

Extension role information is Information about new agricultural policy, farmer's empowerment and management of agricultural institution as well as establishing good relationships between agricultural extension workers and the community. Table 7 presents the usage of information source by agricultural extension workers on extension role information. Most of agricultural extension workers use interpersonal source followed by printed media, personal experience, scientific meeting and electronic media.

a. Interpersonal source

The interpersonal sources consist of discussion with agricultural researchers, discussion with senior officers, discussion colleagues, discussion with farmers, and correspondence with researchers. Forty seven percent of the agricultural extension workers very frequently seek information by discussing with colleagues, 43.1 percent frequently discuss with farmers, and 1 percent very frequently discuss with agricultural researcher, and 1.1 percent correspond with researcher. They frequently discuss with senior officer (39.8 percent) and 43.1 percent frequently discuss with farmers in seeking information. Agricultural extension workers seldom discuss with agricultural researcher (30.9 percent) and 56.9 percent never correspond with researcher.

b. Printed media

Agricultural extension workers who are seeking for information through printed media obtained it by reading agricultural newspaper, agricultural magazines, brochure/leaflet, textbooks, books published by
TABLE 7. DISTRIBUTION OF THE AGRICULTURAL EXTENSION WORKERS BY FREQUENCY OF USING INFORMATION SOURCE FOR EXTENSION RULE INFORMATION $(\mathrm{N}=18 \mathrm{I})$

\begin{tabular}{lll}
\hline TYPES OF INFORMATION SOURCE & MEAN & $\begin{array}{c}\text { STANDARD } \\
\text { DEVIATION }\end{array}$ \\
\hline a. Interpersonal: & & \\
Discussion with colleagues & 4.33 & 0.74 \\
Discussion with farmers & 3.97 & 1.06 \\
Discussion with senior officers & 3.73 & 0.93 \\
Discussion with agricultural researchers & 2.02 & 0.89 \\
Correspondence with researchers & 1.69 & 0.95 \\
Overall & 3.15 & 0.91 \\
b. Printed Media: & & \\
Agricultural newspapers & 3.37 & 1.17 \\
Agricultural magazines & 3.06 & 0.95 \\
Brochure/leaflet & 2.88 & 0.82 \\
Text books & 2.36 & 0.90 \\
Books published by the AARD & 2.31 & 0.84 \\
Journals & 2.27 & 0.82 \\
Overall & 2.71 & 0.92 \\
c. Personal Experience: & & \\
Own observation and experience & 2.99 & 1.03 \\
Own tests and research & 2.13 & 0.91 \\
Overall & 2.56 & 0.97 \\
d. Scientific Meeting: & & \\
Training & 2.58 & 1.03 \\
Seminars & 2.40 & 0.91 \\
Field research project & 1.93 & 0.86 \\
Overall & 2.30 & 0.93 \\
e. Electronic Media: & & \\
Television & 2.78 & 1.14 \\
Radio & 2.73 & 1.13 \\
Video & 1.81 & 0.94 \\
Internet & 1.66 & 0.84 \\
Overall & 2.24 & 1.01 \\
\hline & & \\
\hline
\end{tabular}

Scale: $1=$ Never, $2=$ Seldom, $3=$ Occasionally $4=$ Frequently, $5=$ Very Frequently

AARD, and journals. Agricultural extension workers seldom seek information by journals (50.3 percent). Agricultural extension workers occasionally use brochure/leaflet for seeking the information (46.4 percent). Agricultural extension workers frequently use agricultural newspapers (35.4 percent). There is no agricultural extension worker using books published by the AARD and journal in seeking information.

c. Personal experience

Agricultural extension workers seeking information by 
personal experience do it through own observation and experience; and own test and research. Agricultural extension workers seldom got information through own test and research (47.5 percent), and 37 percent of the agricultural extension workers occasionally seeking information through own observation and experience, and 1.7 percent of the agricultural extension workers very frequently seek information through own test and research. They never seek information through own test and research (24.3 percent).

d. Scientific meeting Agricultural extension workers, who use scientific meeting source in seeking information, got it through seminar (44.2 percent), 30.9 percent occasionally seeking information through training and 44.2 percent seldom seek information through field research project. Thirty-four percent of the agricultural extension workers never seek information through field research project and only 0.6 percent of the agricultural extension workers seeking information through field research project.

e. Electronic media

Electronic media that the agricultural extension workers use in seeking information consist of television, radio, video, and Internet. Agricultural extension workers never use the Internet (52.5 percent), and 33.1 percent agricultural extension workers seldom use Internet and only 1.1 percent of the agricultural extension workers use Internet in seeking the information. Agricultural extension workers occasionally use television (33.1 percent); use radio (39.8 percent) and 45.9 percent of the agricultural extension workers never use the video.

Comparison Between Types of Information with Information Sources Used by Agricultural Extension Workers

Table 8 below shows the comparison between types of information with information sources used by agricultural extension workers. Most of the agricultural extension workers use interpersonal source in seeking information (mean $=3.13 ; \mathrm{SD}=0.774)$, followed by printed media $($ mean $=2.70 ; \mathrm{SD}=0.926)$ and personal experience source $($ mean $=2.52 ; \mathrm{SD}=0.939)$ for extension service information.

TABLE 8. COMPARISON OF USE OF SOURCES OF INFORMATION BY TYPES OF INFORMATION $(\mathrm{N}=181)$

\begin{tabular}{lllllll}
\hline & \multicolumn{2}{l}{ Types of information } & & & \\
\cline { 2 - 7 } Source of information & $\begin{array}{l}\text { Extension service } \\
\text { information }\end{array}$ & \multicolumn{2}{l}{$\begin{array}{l}\text { Innovation } \\
\text { information }\end{array}$} & \multicolumn{2}{l}{$\begin{array}{l}\text { Extension role } \\
\text { information }\end{array}$} \\
\cline { 2 - 7 } & Mean & SD & Mean & SD & Mean & SD \\
\hline Interpersonal & 3.13 & 0.774 & 3.17 & 0.864 & 3.15 & 0.915 \\
Printed media & 2.70 & 0.926 & 2.76 & 0.892 & 2.71 & 0.918 \\
Personal experience & 2.52 & 0.939 & 2.66 & 0.965 & 2.56 & 0.971 \\
Scientific meeting & 2.30 & 0.881 & 2.34 & 0.885 & 2.30 & 0.934 \\
Electronic media & 2.28 & 1.057 & 2.44 & 1.058 & 2.24 & 1.015 \\
\hline
\end{tabular}

Scale: 1: Never; 2: Seldom; 3: Occasionally; 4: Frequently; 5: Very Frequently

Agricultural extension workers seldom used scientific meeting and electronic media source, but for innovation information more agricultural extension workers used electronic media than scientific meeting. This causes agricultural extension workers to need more information innovation and besides that new innovation is easier to be received through electronic media. For innovation information, most of agricultural extension workers use interpersonal source in seeking information $($ mean $=$ 3.17 ; $\mathrm{SD}=0.864$ ), followed by printed media and personal experience. Agricultural extension workers seldom used electronic media and scientific meeting. For extension role information, most of agricultural extension workers use interpersonal source in seeking information (mean $=3.15 ; \mathrm{SD}=0.915)$, followed by printed media and personal experience. Agricultural extension workers seldom used scientific meeting and electronic media.

From three types of information, most of the agricultural extension workers used all information sources for seeking the innovation information followed by extension role information and extension service information. The interpersonal sources are able to provide details information so as to allow individuals to change their strongly held attitude. Agricultural extension workers most often used the interpersonal source because of the existence of the emotional nearness factor through interaction of contact in implementation of the task.

This finding is consistent with Suryantini (2003) who found source of information that most often used by agricultural extension workers is interpersonal source. The finding is in line with the previous study done by Iskak (2005) that most the potato farmers used interpersonal source as a source of information. This finding was consistent with Rogers (1995) that information source 
used by agricultural extension worker can be divided into interpersonal, mass media. The interpersonal sources are able to provide details information so as to allow individuals to change their strongly held attitude. It involves face to face exchange between two or more individuals. In other words, mass media have been viewed as playing a significant role to distribute information during the knowledge stage, while the interpersonal sources are important as the evaluation stage before making decision to consider whether to adopt or not the new idea.

\section{CONCLUSIONS}

Based on findings and results of the study, the following conclusions are drawn:

1. Agricultural extension workers needed extension service information, innovation information, and extension role information; which innovation information was the most required. Innovation information was information about new innovation, advantages and disadvantages of new innovation which were seen from technical, economic and social aspects; disseminating of new innovation and farmer's responses on new innovation as well. The innovation information was chosen because the farmers desired more up-to-date information about agriculture as agricultural extension workers also required much information to carry out their work. This means innovation information was used to increase farmer's knowledge by introducing new agricultural innovation. Meanwhile, extension service information was used by agricultural extension workers to facilitate extension such as extension preparation, giving agricultural information and evaluating the extension activities that have been carried out. In the meantime, extension role information was applied for formulating new agricultural policy.

2. Agricultural extension workers utilized many sources of information in various types of information. Interpersonal source of information was employed by means of discussing with colleagues, farmers and senior officers. They also made use of printed media, such as agricultural newspapers and agricultural magazines for extension service information, innovation information, and extension role information.
Personal experience as source of information which was obtained from own observation and own experience. Electronic media, like television and radio, were mainly referred for innovation information. However, scientific meeting (training, seminar and field research project) was rarely applied for seeking information.

\section{RECOMMENDATIONS}

Based on the findings of the study, the recommendations are as follows:

1. The agricultural department

a. The study found that agricultural extension workers were still limited in using facilities from inside the institution, such as the facilities of printed media and electronic media. Therefore, it was recommended that the agricultural department give more facilities to the agricultural extension workers, such as agricultural magazines, agricultural newspapers, and computers which connect to Internet so that the agricultural extension workers were easy to access newer and up-to-date information, and could follow the development in agricultural field.

b. The study showed that merely a few agricultural extension workers had experience in training and seminar. Hence, it could be recommended that the agricultural department intensified the training implementation for agricultural extension workers to increase their knowledge and experience.

c. The study indicated that the agricultural extension workers needed to get innovative information. For that reason, it was recommended publishing the brochures or leaflets which contain up-to-date and the newest information about agriculture innovation before being sent to the farmers.

d. The agricultural department should increase collaboration with the researchers, so that their research's findings could be disseminated to agricultural extension workers.

2. The agricultural researchers

a. Results of the study showed that relationship between the agricultural extension workers and the 
agricultural researchers was not yet established well. Consequently, it was recommended that the researchers increased the intensity of communication with the agricultural extension workers as well as distributed their research publications.

b. The agricultural researchers should conduct study by involving the agricultural extension workers and the farmers in order to be able knowing the problems of agricultural extension workers.

c. The researchers should frequently publish their research findings. The information provided in publications can be used as extension materials by subject matter specialist.

3. The agricultural extension workers

a. The study showed that the agricultural extension workers rarely discussed and corresponded as well with the researchers. Accordingly, it could be recommended activating of communication between the agricultural extension workers with the researchers, both through discussions and correspondence. This matter was done so that agricultural extension worker could be helped to get the newest research's findings and new agricultural innovation. Moreover agricultural extension workers could also be helped to solve the problems dealing with the farmers.

b. The agricultural extension workers should actively search the up-to-date agriculture information through various media.

c. The agricultural extension workers should routinely subscribe the newspapers and the agricultural magazines in order to widen the territory or area of seeking information from various information sources, and to get up-to-date information as well.

\section{REFERENCES}

Babbie, E. (2004). The practice of social research (10 th edition). Belmont: Wadsworth.

Ban. A.W \& Hawkins. H.S. (1996). Agricultural extension ( $2^{\text {nd }}$ edition). Oxford: Blackwell Science

Giles, T. \& Stanfield, M. (1990). The farmer as manager ( $2^{\text {nd }}$ edition). Wallingford: CAB International. Harun, H.R. (2001). Promoting farmer's participation through the farmer's group approaches. In E. Abdurrachman, Hapsari, B. Sugiarto , A. Early, B. Harpini, F.L. Abubakar, N. Hendriana, M. Maulana, Y.E. Harahap, M.H. Saripudin (Ed.), Proceeding of Seminar on Agricultural Technology Transfer and Training (pp. 111-126). Jakarta: Agency for Agricultural Research and Development.

Irawan, B., Nurmanaf, R., Hastuti, E.L, Muslim, C., Supriatna, Y., \& Darwis , V. (2001). Studi kebijaksanaan pengembangan agribisnis komoditi unggulan hortikultura (Policy analysis on the development of agribusiness of main horticultural commodity). Bogor: Pusat Penelitian Sosial Ekonomi Pertanian.

Iskak, P.I. (2005). Information seeking strategy among potato farmers in West Java, Indonesia. Unpublished Master's Thesis, Universiti Putra Malaysia, Malaysia.

Mawardi, S. (2004). The Problem of Agriculture Extension in the Regional Autonomy Era. From World Wide Web. Retrieved July 20, 2007. Available at http:/ /www.smeru.or.id/newslet/2004/ed12/ 200412field3.htm

Rivera, W.M. (2001). Agricultural and rural extension worldwide: Options for institutional reform in the developing countries. Extension, Education and Communication Service, Research, Extension and Training Division. Sustainable Development Department. Food and Agriculture Organization of the United Nations)

Rogers, E.M. (1960). Social change in rural society. A textbook in rural sociology. New York: Appleton Century Crofts, Incs.

Rogers, E.M. (1995). Diffusion of innovations. Third Edition. New York: The Free Press.

Setyorini, E., Suryantini, H., Mulyani, E.K. (2006). Persepsi manfaat warta penelitian dan pengembangan pertanian bagi penyuluh pertanian. Jurnal Perpustakaan Pertanian. Vol. 15, Number 1. Bogor: Pusat Perpustakaan dan Penyebaran Teknologi Pertanian.

Sulaiman, F. (1998). Poverty alleviation programs in agricultural sector: lessons learned and issues. Agro Economic Forum, 16 (2):75-86. Bogor: Center for AgroSocioeconomic Research and Development (CASERD).

Sulaiman, F. (2002). Assessment of agricultural innova- 
tion transfer system in the decentralization era. Agro

Economic Forum, 20 (2: 24-50. Bogor : Center for Agro-

Socioeconomic Research and Development

(CASERD).

Suryantini. H. (2004). Pemanfaatan informasi teknologi pertanian oleh penyuluh pertanian : Kasus di kabupaten Bogor, Jawa Barat. Jurnal Perpustakaan Pertanian Vol. 3, Number 1. Bogor: Pusat Perpustakaan dan Penyebaran Teknologi Pertanian.

Suryantini. H. (2003). Kebutuhan informasi dan motivasi kognitif penyuluh pertanian serta hubungannya dengan penggunaan sumber informasi (Kasus di Kabupaten Bogor, Jawa Barat). Jurnal Perpustakaan Pertanian Vol. 12. Nomor 2. Bogor: Pusat Perpustakaan dan Penyebaran Teknologi Pertanian.

Suvedi, M., Campo, S., \& Lpinski, M.K. (1999). Trends in Michigan farmers' information seeking behaviors and perspective on the delivery of information. Journal of Applied Communications, 83 (3), 33-50.

Van den Ban, A.W. \& Hawkins, H.S. (1996). Agricultural extension. $2^{\text {nd }}$ ed. Victoria: Blackwell Science Pty Ltd

Weiss, A., Van Crowder, L., \& Bernardi, M. (2000).

Communicating agrometeorological information to farming communities. Agricultural and Forest Meteorology, 103, 185-196 